\title{
MEKANISME BAGI HASIL PADA LEMBAGA KEUANGAN MIKRO SYARIAH (Studi Persepsi Nasabah Tentang Pembiayaan Bagi Hasil)
}

\author{
Muhammad Kamal Zubair \\ Sekolab Tinggi Agama Islam Negeri (STAIN) Parepare \\ Email: Kamal_zubair@yaboo.co.id
}

\begin{abstract}
This research is intended to find customer understanding on profit sharing concept on BMT Fauzan Adzimab in Parepare. Customer perception on profit sharing of the BMT shows higher rank on the level of 67\%. This can be seen in some factors: level of understanding, decision on certain object, emotional engagement and behavior because of emotion and attitude. This can happen because of the people understanding and access toward financing system and also the promotion of BMT. The existence of BMT Fauzan Adzimah through profit sharing has provide high positive outcome in community vocation in developing micro business in Parepare.
\end{abstract}

Keyword: Perception, profit sharing, BMT.

\section{Abstrak}

Penelitian ini dilakukan untuk mengetabui tingkat pemahaman nasabah mengenai konsep pembiayaan bagi hasil yang diterapkan BMT Fauzan Adzimab di kota Parepare. Persepsi nasabab terhadap sistem pembiayaan bagi hasil di BMT Fauzan Adzimah menunjukkan nilai tinggi yang mencapai prosentase 67\%. Hal ini dapat dilibat pada beberapa faktor, yaitu tingkat pengetabuan, keputusan yang diambil terbadap suatu obyek, keterlibatan emosional secara lebih mendalam dan perilaku serta tindakan terbadap apa yang dilakukan berdasarkan pernyataan antara sikap dan emosi. Hal tersebut dapat terjadi karena tingginya tingkat pengetahuan masyarakat serta tingkat aksesibilitas terbadap sistem pembiayaan bagi hasil yang cukup serta gencarnya gebrakan BMT dalam menggiatkan sosialisasi. Kehadiran BMT Fauzan Adzimah dengan sistem bagi hasil memberikan dampak positif dan kontribusi yang besar dalam pemberdayaan masyarakat miskin serta pengembangan usaba kecil masyarakat kota Parepare dan sekitarnya.

Kata kunci: Persepsi, Bagi Hasil, BMT. 


\section{Latar Belakang Masalah}

Usaha mikro merupakan salah satu sektor yang memiliki peranan penting dalam perekonomian, namun selama ini sektor ini sulit berkembang, disebabkan karena pengusaha mikro yang umumnya berasal dari masyarakat lapisan bawah nyaris tidak tersentuh (undeserved) dan dianggap tidak memiliki potensi dana oleh lembaga keuangan formal terutama lembaga keuangan konvensional, sehingga menyebabkan laju perkembangannya terhambat. Akibatnya, aksesibilitas dari pengusaha mikro terhadap sumber keuangan formal rendah, sehingga kebanyakan mereka hanya mengandalkan modal terbatas pada apa yang mereka miliki. Tidak jarang pengusaha mikro mengambil jalan pragmatis untuk memenuhi kebutuhan modalnya dengan mencari pinjaman kepada lembaga keuangan informal seperti rentenir yang menjalankan pola kredit yang praktis dan sederhana tanpa proses administrasi yang rumit dan tidak memakan waktu yang lama.

Dengan adanya permasalahan seperti itu, maka BMT merupakan salah satu sarana yang penting bagi pengusaha kecil tersebut, karena BMT yang juga dapat disebut Balai Usaha Mandiri Terpadu memiliki pengertian sebagai lembaga keuangan mikro yang dioperasikan dengan prinsip bagi hasil, menumbuh kembangkan bisnis usaha mikro dalam rangka mengangkat derajat dan martabat serta membela kepentingan kaum fakir miskin, ditumbuhkan atas prakarsa dan modal awal dari tokoh-tokoh masyarakat setempat dengan berlandaskan pada sistem ekonomi islam.

Sistem keuangan syariah telah memformulasikan sistem interaksi kerja yang dapat menghindari aspek-aspek negatif, yaitu dengan menerapkan beberapa sistem, di mana harus diciptakan lembaga keuangan syariah yang tidak bekerja atas dasar bunga melainkan atas sistem bagi hasil. (Karim, 2004: 36).

Sistem bagi hasil merupakan sistem di mana dilakukan perjanjian atau ikatan bersama di dalam melakukan kegiatan usaha. Di dalam usaha tersebut diperjanjikan adanya pembagian hasil atas keuntungan yang akan diperoleh antara kedua belah pihak atau lebih. Bagi hasil dalam lembaga keuangan syariah merupakan ciri khusus yang ditawarkan kapada masyarakat, dan di dalam 
aturan syariah yang berkaitan dengan pembagian hasil usaha harus ditentukan terlebih dahulu pada awal terjadinya kontrak (akad).

Besarnya penentuan nisbah bagi hasil antara kedua belah pihak ditentukan sesuai kesepakatan bersama, dan harus terjadi dengan adanya kerelaan (an-tarodhin) di masing-masing pihak tanpa adanya unsur paksaan. Salah satu pihak tidak diperkenankan mengambil seluruh keuntungan tanpa membagi kepada pihak yang lain. Selain itu proporsi keuntungan masing-masing pihak harus diketahui pada waktu berkontrak dan proporsi tersebut harus dari keuntungan.

Bentuk-bentuk kontrak kerjasama bagi hasil dalam lembaga keuangan syariah secara umum dapat dilakukan dalam empat akad, yaitu musyarakah, mudharabah, muzara'ah dan musaqah. Namun, dalam penerapannya, prinsip yang digunakan pada sistem bagi hasil, umumnya menggunakan kontrak kerjasama pada akad musyarakah dan mudharabah.

Dalam menjalin beberapa ketentuan transaksi antara BMT dan nasabah, telah diatur beberapa hal yang berkaitan dengan mekanisme kesepakatan (akad) pembiayaan dan mekanisme pelaksanaan bagi hasil. Aturan mengenai hal tersebut secara teoritis berkiblat pada perspektif literatur fiqh klasik muamalah yang kemudian direaktualisasikan oleh para praktisi dan akademisi keuangan syariah kontemporer.

Berkaitan dengan pembiayaan bagi hasil, tentunya tidak terlepas dari keterkaitannya dengan masyarakat, baik itu selaku nasabah maupun non nasabah. Salah satu kaitan tersebut adalah tentang bagaimana sebetulnya masyarakat memahami ataupun mempersepsikan pembiayaan bagi hasil tersebut. Pengertian persepsi secara garis besarnya adalah bagaimana sebenarnya individu memahami suatu obyek atau target berdasarkan pengamatan yang telah dilakukannya berlandaskan pengetahuan yang telah diperoleh dari ilmu yang berkaitan. (Rivai, 2003: 231)

Penelitian ini dilakukan untuk mengetahui tingkat pemahaman nasabah mengenai konsep pembiayaan bagi hasil yang diterapkan BMT Fauzan Adzimah di kota Parepare. Dalam kaitannya dengan nasabah, selama ini BMT Fauzan Adzimah telah melakukan 
dua kegiatan, yaitu menabung atau menitip dan meminjamkan dana dengan menawarkan akad-akad pembiayaan dalam bentuk fasilitas pembiayaan bagi hasil, sebagaimana yang ditawarkan oleh lembaga keuangan Islam lainnya.

\section{Permasalahan}

Berdasarkan uraian latar belakang yang telah dipaparkan diatas, persoalan yang akan dibahas dalam penelitian ini yaitu :

1. Apakah nasabah BMT Fauzan Adzimah telah memahami konsep pembiayaan bagi hasil pada waktu melaksanakan akad?

2. Faktor-fakor apakah yang mempengaruhi persepsi nasabah tentang konsep bagi hasil di BMT Fauzan Adzimah?

\section{Tinjauan Pustaka}

Penelitian mengenai sistem bagi hasil ini bukanlah yang pertama yang pernah dilakukan. Masudul Alam Choudhury (1986) mencermati prinsip bagi untung (profit sharing) pada mudharabah. Dia mengartikan mudharabah sebagai suatu kerjasama kemitraan yang didalamnya masing-masing menyertakan modal, pengelola ataupun perusahaan dengan kesepakatan untuk berbagi keuntungan dalam bentuk persentase. Dalam pandangannya, mudharabah terjadi hanya untuk memperoleh keuntungan dari masing-masing pihak. Pandangan ini berbeda dengan pandangan bahwa mudharabab merupakan kerjasama kemitraan dalam keuntungan maupun kerugian.

Zaidi Satar (1992) mengetengahkan pemikiran dan tulisan banyak tokoh ekonomi Islam mulai dari segi etika moral ekonomis bagi untung rugi hingga konsekuensi maupun model investasi dinamis pembagian untung rugi. Ulasan tiap bagiannya sangat mendukung dalam kerangka berpikir tentang realisasi pemikiran moralitas kepada realitas ekonomi sehingga sistim bagi hasil sebagai prinsip pembiayaan pada lembaga keuangan syariah selanjutnya dikenali secara utuh.

Menurut kamus bahasa Indonesia, bagi hasil diartikan sebagai pemberian perolehan suatu usaha kepada mitra usaha atas keikutsertaan modal atau kerja pengelolaan dalam jumlah yang ditentukan 
bersama sebelumnya. Secara rinci pengertian kata hasil menunjuk pada perolehan atau pendapatan. Disini bagi hasil dapat mengandung pengertian bagi perolehan revenue sharing, bagi untung rugi profit-and loss sharing dan bagi untung profit sharing.

Dalam teknik penghitungan, dikenal dua istilah bagi hasil yang terdiri dari bagi untung (profit sharing) dan bagi pendapatan (revenue sharing). Oleh karena itu, mekanisme perhitungan nisbah bagi hasil yang diterapkan di dalam lembaga keuangan syariah terdiri dari dua sistem, yaitu profit sharing dan revenue sharing.

Profit sharing menurut etimologi Indonesia adalah bagi keuntungan. Dalam kamus ekonomi diartikan pembagian laba. Profit secara istilah adalah perbedaan yang timbul ketika total pendapatan (total revenue) suatu perusahaan lebih besar dari biaya total (total cost). Sedangkan revenue sharing berasal dari bahasa Inggris yang terdiri dari dua kata yaitu, revenue yang berarti; hasil, penghasilan, pendapatan dan sharing adalah bentuk kata kerja dari share yang berarti bagi atau bagian. Revenue sharing berarti pembagian hasil, penghasilan atau pendapatan.

Lembaga keuangan syariah memperkenalkan sistem pada masyarakat dengan istilah revenue sharing, yaitu sistem bagi hasil yang dihitung dari total pendapatan pengelolaan dana tanpa dikurangi dengan biaya pengelolaan dana. Sistem revenue sharing berlaku pada pendapatan yang akan dibagikan dihitung berdasarkan pendapatan kotor (gross sales), yang digunakan dalam menghitung bagi hasil untuk produk pendanaan bank.

Nisbah keuntungan adalah salah satu rukun yang khas dalam akad pembiayaan, yang tidak ada dalam akad jual beli. Nisbah ini mencerminkan imbalan yang berhak diterima oleh kedua belah pihak yang bekerja sama. Pengelola dana mendapatkan imbalan atas kerjanya, sedangkan pemilik dana mendapatkan imbalan atas penyertaan modalnya. Nisbah keuntungan inilah yang akan mencegah terjadinya perselisihan antara kedua belah pihak mengenai cara pembagian keuntungan, adapun nisbah keuntungan harus dinyatakan dalam bentuk prosentase antara kedua belah pihak.

Penentuan nisbah ditentukan berdasarkan kesepakatan, bukan pada porsi setoran modal, walaupun dapat juga bila di- 
sepakati ditentukan nisbah keuntungan sebesar porsi setoran modal. (Muhammad, 2003: 184). Semuanya tergantung pada kesepakatan kedua belah pihak, baik nisbah masing-masing sama atau lebih besar atau lebih kecil dan harus ditepati. Sebab umat Islam terikat dengan syarat-syarat yang telah mereka sepakati. (Muhammad, 2001: 63).

Apabila laba bisnisnya besar, kedua belah pihak mendapat bagian yang besar pula. Bila laba bisnisnya kecil, mereka mendapat bagian kecil juga. Filosofi ini hanya dapat berjalan jika nisbah laba ditentukan dalam bentuk prosentase, bukan dalam bentuk nominal rupiah tertentu. (Sumiyanto, 2005: 10)

Pembagian keuntungan umumnya dilakukan dengan mengembalikan lebih dahulu modal yang ditanamkan pemilik dana, namun kebanyakan ulama menyetujui bila kedua belah pihak sepakat membagi keuntungan tanpa mengembalikan modal. Hal ini berlaku sepanjang kerjasama masih berlangsung. Para ulama berbeda pendapat tentang keabsahan menahan untung, bila keuntungan telah dibagikan, setelah itu usaha mengalami kerugian, sebagian ulama berpendapat, bahwa pengelola akan diminta menutupi kerugian tersebut dari keuntungan yang telah dibagikan kepadanya. (Dewi, 2005: 128).

\section{Metode Penelitian}

Penelitian ini adalah penelitian lapangan. Metode penelitian yang digunakan adalah deskriptif, yaitu suatu metode penelitian yang dilakukan dengan tujuan untuk membuat gambaran atau deskripsi tentang suatu keadaan secara obyektif. Penelitian ini hanya melukiskan keadaan objek atau persoalannya dan tidak dimaksudkan untuk mengambil atau menarik simpulan yang berlaku umum.

Penelitian ini mengambil lokasi di Kantor BMT Fauzan Adzimah yang berlokasi di Kota Parepare. Populasi dalam penelitian ini adalah seluruh nasabah pembiayaan mudharabah di BMT Fauzan Adzimah. Sampel yang akan menjadi responden sebanyak 40 orang. Pengambilan sampel dalam penelitian ini menggunakan teknik Non Random (Non Probability) Sampling. 


\section{Pembahasan}

Salah satu fungsi utama BMT sebagai lembaga keuangan syariah adalah sebagai lembaga perantara keuangan (financial intermediary) antara pihak yang kelebihan dana dengan pihak yang membutuhkan dana. Untuk melaksanakan fungsi tersebut BMT dituntut harus dapat melakukan manajemen dengan baik, di antaranya adalah manajemen penghimpunan dana.

Penghimpunan dana dalam BMT Fauzan Adzimah tidak jauh berbeda dengan bank syariah yang juga salah satu fungsinya sebagai lembaga perantara (financial intermediary). Kegiatan selanjutnya setelah BMT melakukan penghimpunan dana pada pihak-pihak pemilik dana, maka BMT dituntut harus melempar dana tersebut ke sektor pembiayaan untuk disalurkan ke masyarakat yang membutuhkan. Hal demikian dilakukan terkait dengan fungsi BMT sebagai lembaga perantara keuangan, dan dengan melakukan pembiayaan itulah BMT akan memperoleh pendapatan.

Lembaga keuangan mikro non bank seperti BMT memiliki fungsi yang hampir sama dengan perbankan, yaitu sebagai lembaga intermediasi bagi kelompok surplus dana (debitur) dengan kelompok minus dana (kreditur). Fungsi ini dijalankan dengan baik oleh BMT Faudzan Adzimah, sehingga dana pihak ketiga yang menjadi simpanan nasabah dapat disalurkan kembali dalam bentuk pembiayaan dengan imbalan bagi hasil antara BMT dengan nasabah peminjam.

Sasaran pembiayaan yang diberikan oleh BMT adalah pengusaha-pengusaha kecil menengah yang ada di kota Parepare, dan kota sekitarnya yang berniat mengembangkan usahanya. Berbagai kiat dilakukan BMT untuk menarik dan meyakinkan calon nasabah akan keunggulan sistem bagi hasil yang merupakan dasar operasional BMT faudzan Adzimah

Dalam penelitian ini, obyek yang diteliti adalah seluruh nasabah pembiayaan bagi hasil di BMT Faudzan Adzimah dengan jumlah nasabah pembiayaan bagi hasil adalah 300 orang yang aktif. Mengingat jumlah nasabah yang dijadikan responden cukup besar, maka diambil sampel yang sekiranya dapat mewakili dari keseluruhan populasi dengan menggunakan teknik proporsional sampling. 


\section{a. Persepsi Nasabah BMT Terhadap Sistem Bagi Hasil}

Persepsi sebagai suatu hal yang bersifat kognitif pada diri seseorang sebagai dasar pijakan terhadap suatu hal yang akan dilakukan. Suatu tindakan yang baik biasanya didasari dengan adanya suatu persepsi yang baik akan hal tersebut. Hubungan persepsi nasabah terhadap pembiayaan bagi hasil di BMT dapat dilihat pada tabel berikut :

\begin{tabular}{cccc}
\hline Kategori & Interval & Frekwensi & Persentase \\
\hline Tinggi & $51-75$ & 67 & $67 \%$ \\
Sedang & $26-50$ & 27 & $27 \%$ \\
Rendah & $5-25$ & 6 & $6 \%$ \\
Jumlah & & & \\
\hline
\end{tabular}

Sumber : Data primer

Dari tabel di atas, persepsi nasabah terhadap sistem pembiayaan bagi hasil menunjukkan nilai paling tinggi yang mencapai prosentase $67 \%$ menempati kategori tinggi. Hal ini dapat dilihat pada beberapa faktor, yaitu tingkat pengetahuan, keputusan yang diambil terhadap suatu obyek, keterlibatan emosional secara lebih mendalam dan perilaku serta tindakan terhadap apa yang dilakukan berdasarkan pernyataan antara sikap dan emosi. Hal tersebut dapat terjadi karena tingginya tingkat pengetahuan masyarakat serta tingkat aksesibilitas terhadap sistem pembiayaan bagi hasil yang cukup serta gencarnya gebrakan BMT dalam menggiatkan promosi dan sosialisasi.

\section{b. Dampak Sistem Bagi Hasil Bagi Masyarakat}

Sejak didirikan pada tanggal 8 juli 1998, BMT Fauzan Adzimah tetap eksis dan terus mengalami kemajuan. Eksistensi tidak terpengaruh oleh berbagai goncangan ekonomi. Hal ini disebabkan karena masyarakat Parepare khususnya pelaku usaha kecil tetap mengutamakan BMT Fauzan Adzimah sebagai mitra penyedia layanan modal usaha yang dalam operasionalnya menerapkan konsep bagi hasil sebagai pengganti bunga. Fenomena tersebut dapat dijadikan jawaban sementara bahwa penerapan sistem bagi hasil dalam pelayanan pembiayaan/ kredit dapat menjembatani 
pelaku usaha kecil (mikro) dengan pihak penyedia layanan modal (perbankan) yang selama ini termarginalkan oleh sistem kelayakan usaha bank konvensional.

Dampak yang unik terjadi pada pembiayaan bagi hasil, di mana fluktuasi pada sektor riil mengakibatkan pendapatan yang bervariasi namun stabil. Pendapatan yang relatif stabil seperti itu akan berdampak pada bagi hasil yang diberikan kepada nasabah investor di sisi liabilitas. Bagi hasil yang diberikan kepada nasabah investor secara individual relatif sama dengan bulan-bulan sebelumnya, walaupun kecil dibandingkan dengan suku bunga pada bank konvensional yang merangkak naik akibat naiknya suku bunga Bank Indonesia.

Ini menunjukkan bahwa meskipun belum dibuktikan bahwa komitmen pada lembaga keuangan syariah ada pada kalangan menengah ke bawah. Demikian pula pada BMT Fauzan Adzimah, dana-dana yang terhimpun masih lebih banyak didominasi oleh nasabah kecil. Tingkat pengetahuan umat terhadap lembaga keuangan syariah yang cukup tinggi menjadi salah satu penyebab tingginya minat masyarakat menitipkan dananya.

Besarnya dana yang berhasil dihimpun oleh BMT akan ikut mendongkrak laju perkembangan BMT itu sendiri. Sebab semakin besar dana masyarakat yang dihimpun maka secara otomatis semakin banyak pula dana yang bisa disalurkan pada sektor pembiayaan. Dan dengan demikian semakin banyak sektor usaha mikro masyarakat yang dapat dibantu yang selama ini menjadi fokus dari penyaluran dana pembiayaan BMT Fauzan Adzimah Parepare pada khususnya. Dan tentunya pergerakan dana oleh BMT ini juga menjadi pergerakan serta perbaikan kembali kondisi perekonomian masyarakat kota Parepare dan sekitarnya.

\section{Kesimpulan}

Lembaga keuangan mikro non bank seperti BMT memiliki fungsi yang hampir sama dengan perbankan, yaitu sebagai lembaga intermediasi bagi kelompok surplus dana (debitur) dengan kelompok minus dana (kreditur). Fungsi ini dijalankan dengan baik oleh BMT Fauzan Adzimah, sehingga dana pihak ketiga yang menjadi 
simpanan nasabah dapat disalurkan kembali dalam bentuk pembiayaan dengan imbalan bagi hasil antara BMT dengan nasabah peminjam.

Sasaran pembiayaan yang diberikan oleh BMT adalah pengusaha-pengusaha kecil menengah yang ada di kota Parepare, dan kota sekitarnya yang berniat mengembangkan usahanya. Berbagai kiat dilakukan BMT untuk menarik dan meyakinkan calon nasabah akan keunggulan sistem bagi hasil yang merupakan dasar operasional BMT Fauzan Adzimah.

BMT Fauzan Adzimah tidak hanya membatasi pemberian pembiayaan kepada sektor usaha yang mapan saja atau hanya kepada nasabah yang mampu meneyediakan jaminan saja, tetapi juga memberikan pembiayaan kepada usaha kecil, bahkan pengusaha pemula sekalipun.

Persepsi nasabah terhadap sistem pembiayaan bagi hasil di BMT Fauzan Adzimah menunjukkan nilai tinggi yang mencapai prosentase $67 \%$. Hal ini dapat dilihat pada beberapa faktor, yaitu tingkat pengetahuan, keputusan yang diambil terhadap suatu obyek, keterlibatan emosional secara lebih mendalam dan perilaku serta tindakan terhadap apa yang dilakukan berdasarkan pernyataan antara sikap dan emosi. Hal tersebut dapat terjadi karena tingginya tingkat pengetahuan masyarakat serta tingkat aksesibilitas terhadap sistem pembiayaan bagi hasil yang cukup serta gencarnya gebrakan BMT dalam menggiatkan sosialisasi.

Besarnya dana yang berhasil dihimpun oleh BMT akan ikut mendongkrak laju perkembangan BMT itu sendiri. Sebab semakin besar dana masyarakat yang dihimpun maka secara otomatis semakin banyak pula dana yang bisa disalurkan pada sektor pembiayaan. Dan dengan demikian semakin banyak sektor usaha mikro masyarakat yang dapat dibantu yang selama ini menjadi fokus dari penyaluran dana pembiayaan BMT Fauzan Adzimah Parepare pada khususnya. Dan tentunya pergerakan dana oleh BMT ini juga menjadi pergerakan serta perbaikan kembali kondisi perekonomian masyarakat kota Parepare dan sekitarnya. 


\section{Daftar Pustaka}

Choudhury, Masudul Alam. 1986. Contributions to Islamic Economic Theory : a Study in Social Economics. New York : St. Martin's Press.

Dewan Syari'ah Nasional. 2001. Himpunan Fatwa Dewan Syari'ah Nasional Untuk Lembaga Keuangan Syari'ah, Ed. 1, (Diterbitkan atas Kerjasama Dewan Syari'ah Nasional-MUI dengan Bank Indonesia), h. 87

Dewi, Gemala dkk. 2005. Hukum Perikatan Islam di Indonesia, Ed.1.Cet.1. Jakarta: Kencana.

Karim, Adiwarman. 2004. Bank Islam: Analisis Fiqih dan Keuangan, Edisi 2. Jakarta: PT. Raja Grafindo. .1989. Kamus Besar Bahasa Indonesia. Jakarta: Balai Pustaka.

Lowes, Cristopher Pass dan Bryan. 1994. Kamus Lengkap Ekonomi, Edisi ke-2. Jakarta: Erlangga.

Marzuki. 2002. Metodologi Riset. Yogyakarta: BPFE-UII.

Muhammad. 2003. Konstruksi Mudharabah dalam Bisnis Syari'ah : Mudharabah dalam Wacana Fiqh dan Praktik Ekonomi Modern, Cet-1. Yogyakarta: Pusat Studi Ekonomi Islam (PSEI).

.2001. Teknik Perbitungan Bagi Hasil di Bank Syariah. Yogyakarta: UII Press.

Ridwan, Muhammad. 2004. Manajemen Baitul Maal Watamwil. Yogyakarta: UII Press.

Satar, Zaidi (ed). 1412 H-1992 M. Resource Mobilization and Investment in An Islamic Economic Framework. U.S.A : the international institute of islamic thought.

Shadily, John M. Echols dan Hassan. 1995. Kamus Inggris Indonesia, Cet. ke-21. Jakarta : PT. Gramedia.

Sumiyanto, Ahmad. 2005. Problem dan Solusi Transaksi Mudharabah. Yogyakarta: Magistra Insania Press. 